\title{
PPARa signal pathway gene expression is associated with fatty acid content in yak and cattle longissimus dorsi muscle
}

\author{
W. Qin, C.N. Liang, X. Guo, M. Chu, J. Pei, P.J. Bao, X.Y. Wu, T.K. Li and P. Yan \\ Key Laboratory of Yak Breeding Engineering Gansu Province, \\ Lanzhou Institute of Husbandry and Pharmaceutical Sciences, \\ Chinese Academy of Agricultural Science, Lanzhou, China \\ Corresponding authors: P. Yan / W. Qin \\ E-mail: pingyanlz@163.com / qinwen_614@163.com \\ Genet. Mol. Res. 14 (4): 14469-14478 (2015) \\ Received June 27, 2015 \\ Accepted October 8, 2015 \\ Published November 18, 2015 \\ DOI http://dx.doi.org/10.4238/2015.November.18.9
}

ABSTRACT. Intramuscular fatty acid (FA) is related to meat qualities such as juiciness, tenderness, palatability, and shear force. PPARa plays an important role in lipid metabolism in the liver and skeletal muscle. This study investigated FA composition in yaks and cattle, in order to ascertain whether a correlation between PPARa signal pathway genes as candidate genes and meat FA composition in yaks and cattle exists. Statistical analyses revealed that levels of monounsaturated fatty acid (MUFA) and polyunsaturated fatty acid (PUFA) in yaks were significantly higher than those in cattle $(P<0.01)$, whereas saturated fatty acid (SFA) levels were significantly lower than those in cattle $(P<0.05)$. The mRNA expression levels of FABP4 $(P<0.05)$, SCP2 $(P<0.05)$, and APOA1 $(P<0.01)$ in yaks were significantly lower than those in cattle. However, $L P L$ expression in yaks was significantly higher than that in cattle $(P<0.05)$. In yaks, the expression levels of $F A B P 3(P<0.05)$ and $L P L(P<0.01)$ were negatively correlated with MUFA, and those of FABP4 and $S C D$ were positively correlated with PUFA $(P<0.01)$. In cattle, the mRNA level of PLTP was positively correlated with SFA $(P<0.05)$, and $L P L$ was positively correlated 
with MUFA $(P<0.05)$. These results suggest that these genes may participate in the regulation and control of intramuscular FA metabolism in yaks, so they could be used as candidate markers to improve yak meat quality.

Key words: PPARa signal pathway gene; mRNA expression; Yak; Cattle; Fatty acid composition

\section{INTRODUCTION}

In recent years, meat quality has become an important component of consumer demand, particularly yak meat, which is low in fat and cholesterol, and high in protein, vitamins, and essential minerals such as copper, zinc, iron, and potassium (Wan et al., 2012). Yak meat is a staple source of animal protein, and the most important component of economic income for Tibetans living between 2500 and $5500 \mathrm{~m}$ above sea level. Despite the fact that yak meat is not as tender as cattle meat, the economic value of yak meat is high (Niu et al., 2009).

Intramuscular fatty acid (FA) is an important factor that affects meat quality variables such as juiciness, tenderness, palatability, shear force, and muscle pH value (Goodson et al., 2002; Hausman et al., 2009). Intramuscular FA is composed of $60-70 \%$ phospholipids. Several FA groups and single FAs have different physiological effects, and can function as physiological regulators (Cao et al., 2008). The content and composition of intramuscular FA are influenced by several factors, such as breed (Wang et al., 2011), gender, age (Bednárová et al., 2013), and nutrition (Yang et al., 2006).

The content and composition of intramuscular FA are mainly determined by lipid metabolism. Peroxisome proliferator-activated receptors (PPARs), which have three subtypes (PPAR $\alpha$, PPAR $\beta / \delta$, and PPARY), are nuclear hormone receptors that are activated by FAs and their derivatives (Takahashi, 2005). PPAR a plays a role in the clearance of circulating or cellular lipids by the regulation of gene expression involved in lipid metabolism in the liver and skeletal muscle. The expression of many PPARa signaling pathway genes in the longissimus muscles, including those involved in lipid transport [phospholipid transfer protein (PLTP) and apolipoprotein A-I (APOA1)], lipogenesis [malic enzyme 1 (ME1) and stearoyl-CoA desaturase (SCD)], FA transport [diazepam binding inhibitor (DBI), FA binding protein 3 (FABP3), thrombospondin receptor (CD36), and lipoprotein lipase (LPL)], FA oxidation [sterol carrier protein 2 (SCP2)], and adipocyte differentiation [FA binding protein 4 (FABP4)] may contribute to FA deposition. However, whether the expression of lipid metabolic genes is associated with FA deposition within steers is unknown.

This study was conducted in order to identify PPARa signaling pathway genes that are associated with FA content in the longissimus dorsi muscle of yaks and cattle. The mRNA expression levels of 11 PPARa signaling pathway genes, including those involved in lipid transport, lipogenesis, FA transport, FA oxidation, and adipocyte differentiation were measured. Correlations between gene expression levels and FA content were analyzed, and differences in gene expression levels and FA content between yaks and cattle were investigated.

\section{MATERIAL AND METHODS}

\section{Animals}

The eight yaks and eight cattle used were 3 years old and from pastoral areas in the Tibetan Autonomous Prefecture of Gannan, Gansu Province, China. Muscle tissue samples were 
taken from the right side of the longissimus dorsi muscle at the 12th/13th rib. Samples for RNA extraction were collected after slaughter, immediately frozen in liquid nitrogen, and stored at $-80^{\circ} \mathrm{C}$. Samples for FA composition analysis were collected $24 \mathrm{~h}$ after carcass cooling and maintained at $4^{\circ} \mathrm{C}$.

\section{RNA extraction and real-time polymerase chain reaction (PCR)}

Total RNA was extracted from the tissues using an RNAprep Pure Kit (For Tissue) (Tiangen), according to the manufacturer instructions. Total RNA was quantified by absorbance at $260 \mathrm{~nm}$, and its integrity was checked by agarose gel electrophoresis and ethidium bromide staining of the 28 and $18 \mathrm{~S}$ bands. Total RNA was reverse-transcribed into cDNA using a PrimeScript ${ }^{\mathrm{TM}} \mathrm{RT}$ reagent kit (Takara), according to manufacturer instructions. A real-time PCR was conducted with $12.5 \mu \mathrm{L}$ SYBR $^{\circledR}$ Premix Ex Taq ${ }^{\mathrm{TM}}$ II (Takara), $0.2 \mu \mathrm{L} 10 \mu \mathrm{M}$ primers, $9.5 \mu \mathrm{L} \mathrm{ddH}_{2} \mathrm{O}$, and a $1-\mu \mathrm{L}$ total reaction volume that contained $100 \mathrm{ng}$ cDNA. The thermal cycling parameters were as follows: $95^{\circ} \mathrm{C}$ for $5 \mathrm{~s}$, followed by 40 cycles at $95^{\circ} \mathrm{C}$ for $30 \mathrm{~s}$ and $\mathrm{Tm}$ for $30 \mathrm{~s}$. All of the primers were designed using integrated mRNA sequences based on sequences published by the National Center for Biotechnology Information (NCBI) (www.ncbi.nlm.nih.gov; Table 1). The 2- ${ }^{\Delta \Delta \mathrm{Ct}}$ method was used to determine the relative fold-changes (Schmittgen and Livak, 2008), and all of the data were normalized with the housekeeping glyceraldehyde-3-phosphate dehydrogenase gene.

Table 1. Primer sequences used in the real-time polymerase chain reaction.

\begin{tabular}{|c|c|c|c|c|}
\hline Gene name and symbol & GenBank ID & $5^{\prime} \rightarrow 3^{\prime}$ & Sequence & Amplicon size $(b p)$ \\
\hline Glyceraldehyde-3-phosphate dehydrogenase, GAPDH & NM_001034034 & $\begin{array}{l}\text { Forward } \\
\text { Reverse }\end{array}$ & $\begin{array}{l}\text { ccacgagaagtataacaacacc } \\
\text { gtcataagtccctccacgat }\end{array}$ & 120 \\
\hline Phospholipid transfer protein, PLTP & NM_001035027 & $\begin{array}{l}\text { Forward } \\
\text { Reverse }\end{array}$ & $\begin{array}{l}\text { tccatttccagccagacca } \\
\text { ccccatcatagaagaaccagtagag }\end{array}$ & 102 \\
\hline Fatty acid binding protein $3, F A B P 3$ & NM_174313 & $\begin{array}{l}\text { Forward } \\
\text { Reverse }\end{array}$ & $\begin{array}{l}\text { tgtgcgggagatggttga } \\
\text { tgccgagtccaggagtagcc }\end{array}$ & 146 \\
\hline Fatty acid binding protein $4, F A B P 4$ & NM_174314 & $\begin{array}{l}\text { Forward } \\
\text { Reverse }\end{array}$ & $\begin{array}{l}\text { caaattgggccaggaatttga } \\
\text { tctcataaactctggtggcagtgac }\end{array}$ & 197 \\
\hline Lipoprotein lipase, $L P L$ & NM_001075120 & $\begin{array}{l}\text { Forward } \\
\text { Reverse }\end{array}$ & $\begin{array}{l}\text { acttgccacctcattcctg } \\
\text { acccaactctcatacattcctg }\end{array}$ & 119 \\
\hline Thrombospondin receptor, $C D 36$ & NM_174010 & $\begin{array}{l}\text { Forward } \\
\text { Reverse }\end{array}$ & $\begin{array}{l}\text { ggtccttacacatacagagttcg } \\
\text { atagcgagggttcaaagatgg }\end{array}$ & 115 \\
\hline Malic enzyme 1, ME1 & NM_001144853 & $\begin{array}{l}\text { Forward } \\
\text { Reverse }\end{array}$ & $\begin{array}{l}\text { tgctgcgattggtggtgc } \\
\text { tcggaagggtaacgggat }\end{array}$ & 191 \\
\hline Stearoyl-CoA desaturase, $S C D$ & NM_173959 & $\begin{array}{l}\text { Forward } \\
\text { Reverse }\end{array}$ & $\begin{array}{l}\text { actgcggtccaagtcgtt } \\
\text { cagccttgtctggagtcatc }\end{array}$ & 164 \\
\hline Sterol carrier protein $2, \mathrm{SCP} 2$ & NM_001033990 & $\begin{array}{l}\text { Forward } \\
\text { Reverse }\end{array}$ & $\begin{array}{l}\text { tgaactccctttgcctccttt } \\
\text { caggttctattcacccagcactt }\end{array}$ & 171 \\
\hline Apolipoprotein A-I, APOA1 & NM_174242 & $\begin{array}{l}\text { Forward } \\
\text { Reverse }\end{array}$ & $\begin{array}{l}\text { accgtgtatgtggaagcaatcaag } \\
\text { tcccagttgtccaggagtttcag }\end{array}$ & 107 \\
\hline Peroxisome proliferator-activated receptor alpha, $P P A R \alpha$ & NM_001034036 & $\begin{array}{l}\text { Forward } \\
\text { Reverse }\end{array}$ & $\begin{array}{l}\text { gaatcggaataagtgcca } \\
\text { gtttcggaatcttctaggtc }\end{array}$ & 156 \\
\hline Diazepam binding inhibitor, $D B I$ & NM_001113321 & $\begin{array}{l}\text { Forward } \\
\text { Reverse }\end{array}$ & $\begin{array}{l}\text { gcatcttaagaccaagccagcag } \\
\text { ttgcctttgaagtccaacattcc }\end{array}$ & 117 \\
\hline
\end{tabular}

\section{FA composition of intramuscular fat}

Total lipids were extracted from approximately $10 \mathrm{~g}$ longissimus dorsi muscle samples with a chloroform-methanol (1:1) solvent, and the samples were homogenized and then extracted for $24 \mathrm{~h}$ (Yan et al., 2005). Lipid fractions were hydrolyzed in $5 \mathrm{~mL} 2 \mathrm{M} \mathrm{KOH}$ and $\mathrm{CH}_{3} \mathrm{OH}(1: 1)$ after being dissolved in $2 \mathrm{~mL}$ chloroform and petroleum ether-benzene (1:1). After stratification of the petroleum ether methyl ester solution by distilled water, the supernatant was used for gas 
chromatography-mass spectrometry. The chromatographic conditions were as follows: $160^{\circ} \mathrm{C}$ for 2 min, increasing at $5^{\circ} \mathrm{C} / \mathrm{min}$ to $220^{\circ} \mathrm{C}$ for $1 \mathrm{~min}$, then increasing at $8^{\circ} \mathrm{C} / \mathrm{min}$ to $230^{\circ} \mathrm{C}$ for $1 \mathrm{~min}$; the injection port was at $250^{\circ} \mathrm{C}$, the diversion ratio was $60: 1$, the carrier gas was $\mathrm{He}$, and the flow rate was $1.2 \mathrm{~mL} / \mathrm{min}$. The mass spectrometry conditions were as follows: electron ionization mode was set; the ion source temperature was $250^{\circ} \mathrm{C}$, the electron energy was $70 \mathrm{eV}$, the solvent latency was $1.8 \mathrm{~min}$, and the electron multiplier was $1 \times 105 \mathrm{kV}$; full-scan mode was set; the scanning range was 30-450 aum, and the scanning speed was 563/s (Yang et al., 2008).

\section{Statistical analyses}

Data are reported as means and standard deviations. Analyses of variance, independentsample Student $t$-tests, and correlation analyses were performed in SPSS 18.0. Significance was set at the 0.05 level, and $P$ values lower than 0.01 were considered to be extremely significant.

\section{RESULTS}

\section{FA content and composition}

FA content and composition in the longissimus dorsi muscles of yaks were significantly different from those of cattle (Table 2). Yaks contained more C15:0, C16:1, C17:0, C20:0, and C24:0 than did cattle, but had significantly lower levels of saturated fatty acid (SFA) $(P<0.05)$. Yaks had significantly higher levels of C18:1, C18:2n6t, C18:3, C20:4, conjugated linoleic acid (CLA), monounsaturated fatty acid (MUFA), and polyunsaturated fatty acid (PUFA) than cattle, whereas $C 16: 0$ levels were lower than in cattle $(P<0.01)$. Eicosapentaenoic acid (EPA) and docosahexaenoic acid (DHA) were not detected.

Table 2. Fatty acid composition in longissimus dorsi of yaks and cattle (means \pm SD).

\begin{tabular}{lcr}
\hline Fatty acid (\%) & \multicolumn{1}{c}{ Yaks } & Cattle \\
\hline SFA & $49.30 \pm 4.13^{*}$ & $56.11 \pm 5.09$ \\
C10:0 & $0.07 \pm 0.03$ & $0.05 \pm 0.02$ \\
C12:0 & $0.06 \pm 0.01$ & $0.06 \pm 0.02$ \\
C14:0 & $2.49 \pm 0.39$ & $2.32 \pm 0.21$ \\
C15:0 & $0.42 \pm 0.18^{*}$ & $0.16 \pm 0.04$ \\
C16:0 & $21.09 \pm 3.10^{* *}$ & $30.82 \pm 3.21$ \\
C17:0 & $1.12 \pm 0.32^{*}$ & $0.55 \pm 0.14$ \\
C18:0 & $22.72 \pm 2.33$ & $21.16 \pm 2.25$ \\
C20:0 & $0.57 \pm 0.22^{*}$ & $0.41 \pm 0.03$ \\
C22:0 & $0.17 \pm 0.04$ & $0.20 \pm 0.02$ \\
C24:0 & $0.58 \pm 0.15^{*}$ & $0.38 \pm 0.02$ \\
MUFA & $39.91 \pm 2.32^{\star *}$ & $32.03 \pm 1.30$ \\
C16:1 & $4.69 \pm 1.10^{*}$ & $3.24 \pm 0.18$ \\
C17:1 & $0.87 \pm 0.24$ & $0.76 \pm 0.12$ \\
C18:1 & $33.95 \pm 1.48^{\star *}$ & $27.75 \pm 1.18$ \\
PUFA & $6.81 \pm 0.72^{\star *}$ & $3.28 \pm 0.80$ \\
C18:2n6c & $1.58 \pm 0.46$ & $1.30 \pm 0.61$ \\
C18:2n6t & $0.90 \pm 0.27^{\star *}$ & $0.32 \pm 0.09$ \\
C18:3 & $0.98 \pm 0.14^{\star *}$ & $0.57 \pm 0.24$ \\
C20:4 & $1.56 \pm 0.05^{\star *}$ & $0.38 \pm 0.02$ \\
CLA C18:2 & $1.09 \pm 0.28^{*}$ & $0.71 \pm 0.03$ \\
EPA C20:5 & $0.41 \pm 0.05^{\star *}$ & ND \\
DHA C22:6 & $0.29 \pm 0.05^{\star *}$ & ND \\
\hline SFA & & \\
\hline
\end{tabular}

SFA, saturated fatty acid; MUFA, monounsaturated fatty acid; PUFA, polyunsaturated fatty acid; CLA, conjugated linoleic acid; EPA, eicosapentaenoic acid; DHA, docosahexaenoic acid. *Significantly different $(P<0.05)$; ${ }^{* *}$ extremely significantly different $(P<0.01) . N D=$ not detected. 


\section{PPARa signaling pathway gene expression levels}

The expression levels of FABP4 $(P<0.05)$, SCP2 $(P<0.05)$, and APOA1 $(P<0.01)$ in yaks were significantly lower than those in cattle. However, $L P L$ expression in yaks was significantly higher than in cattle $(P<0.0$; Figure 1$)$.

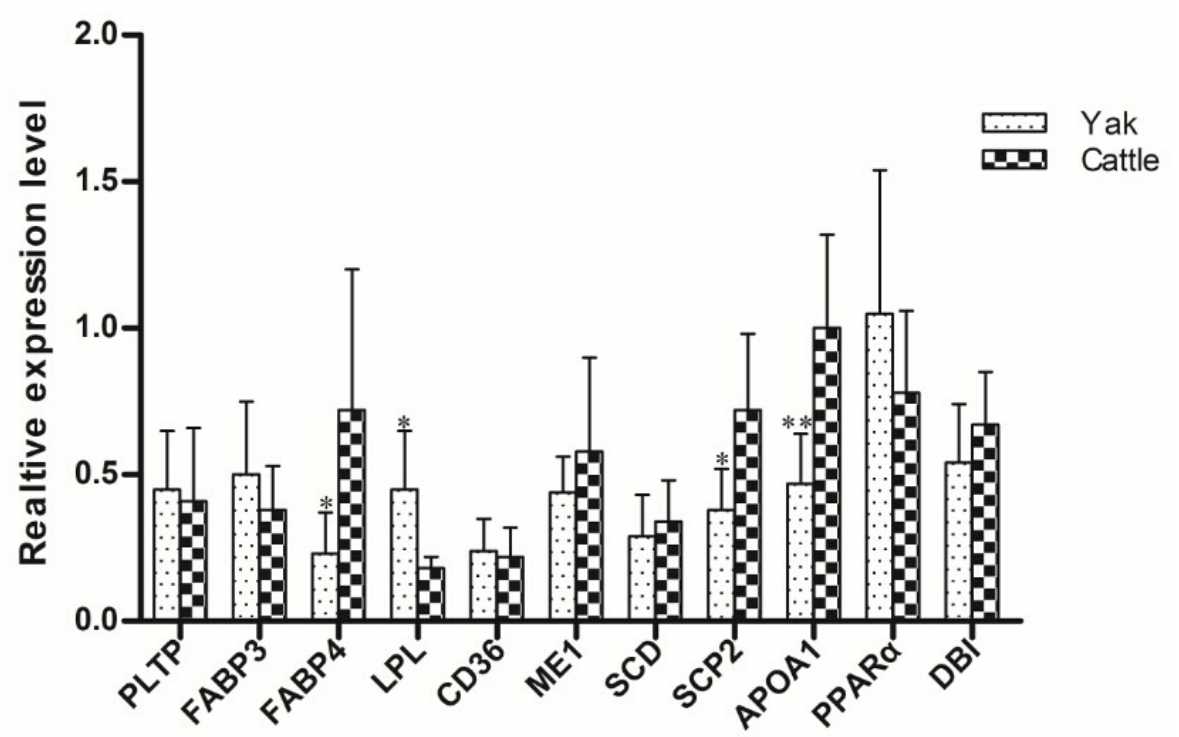

Figure 1. Expression of PPARa signaling pathway genes mRNA in longissimus dorsi of yak and cattle. For abbreviations, see Table 1.

\section{Correlation between gene expression levels and FA content and composition}

Gene expression levels were correlated with FA content. Pearson's correlation coefficients between yak FA content and the expression of each gene are shown in Table 3. Overall, MUFA levels were negatively correlated with the expression levels of FABP3 $(P<0.05)$ and $L P L(P<$ $0.01)$, and PUFA levels were positively correlated with those of FABP4 and $S C D(P<0.01)$. CD36 and APOA1 were both positively correlated with $\mathrm{C} 12: 0$ and $\mathrm{C} 15: 0(\mathrm{P}<0.05)$, and SCP2 was positively correlated with $\mathrm{C} 10: 0, \mathrm{C} 12: 0$, and $\mathrm{C} 14: 0(\mathrm{P}<0.05)$. C22:0 was negatively correlated with FABP4 and $S C D(P<0.05)$. PLTP mRNA expression levels were positively correlated with $C 18: 2 n 6 t(P<0.05)$, whereas $D B I$ mRNA expression levels were negatively correlated with $C 20: 0$ $(\mathrm{P}<0.05)$. No correlations between PPARa expression levels and FAs were found.

Pearson's correlation coefficients between cattle FA content and the expression of each gene are shown in Table 4. The mRNA abundance of PLTP was positively correlated with SFA and C16:0 $(P<0.05)$, and $L P L$ was positively correlated with MUFA and $C 20: 0$ but negatively correlated with $\mathrm{C} 10: 0(\mathrm{P}<0.05)$. APOA1 expression levels were negatively correlated with SFA, $C 16: 0$, and C18:0 $(P<0.05)$. 
Table 3. Correlation coefficients between gene expression level and fatty acid composition in longissimus dorsi of yaks.

\begin{tabular}{|c|c|c|c|c|c|c|c|c|c|c|c|}
\hline Fatty acid (\%) & PLTP & $F A B P 3$ & FABP4 & $L P L$ & $C D 36$ & ME1 & $S C D$ & SCP2 & $A P O A 1$ & PPARa & $D B I$ \\
\hline SFA & 0.400 & -0.387 & -0.119 & -0.212 & -0.398 & 0.072 & 0.044 & 0.150 & -0.253 & -0.448 & 0.063 \\
\hline C10:0 & 0.482 & 0.362 & 0.320 & 0.264 & 0.556 & 0.489 & 0.463 & $0.820^{*}$ & 0.497 & 0.391 & 0.740 \\
\hline C12:0 & 0.073 & 0.557 & 0.280 & 0.363 & $0.897^{\star *}$ & 0.328 & 0.273 & $0.842^{*}$ & $0.858^{*}$ & 0.383 & 0.368 \\
\hline C14:0 & 0.533 & 0.564 & 0.183 & 0.709 & 0.463 & 0.268 & 0.368 & $0.794^{*}$ & 0.495 & 0.614 & 0.721 \\
\hline C15:0 & -0.062 & 0.635 & 0.146 & 0.651 & $0.806^{*}$ & 0.255 & 0.432 & 0.599 & $0.768^{*}$ & 0.346 & 0.214 \\
\hline C16:0 & 0.581 & -0.190 & -0.544 & -0.010 & -0.542 & 0.441 & -0.422 & -0.296 & -0.501 & -0.205 & -0.035 \\
\hline C17:0 & -0.239 & 0.358 & 0.528 & 0.277 & $0.838^{*}$ & 0.159 & 0.065 & 0.630 & 0.716 & 0.238 & 0.342 \\
\hline C18:0 & -0.259 & -0.572 & 0.520 & -0.556 & -0.143 & -0.620 & 0.542 & 0.362 & 0.025 & -0.637 & 0.002 \\
\hline C20:0 & -0.122 & -0.094 & -0.729 & 0.063 & -0.305 & -0.173 & $-0.793^{*}$ & -0.315 & -0.060 & -0.559 & $-0.882^{*}$ \\
\hline $\mathrm{C} 22: 0$ & 0.092 & 0.026 & $-0.779^{*}$ & 0.228 & -0.177 & 0.398 & $-0.813^{*}$ & -0.420 & -0.126 & -0.328 & -0.648 \\
\hline $\mathrm{C} 24: 0$ & 0.705 & 0.261 & -0.342 & 0.177 & -0.039 & $0.801^{*}$ & -0.345 & -0.033 & -0.174 & 0.444 & 0.404 \\
\hline MUFA & -0.268 & $-0.797^{\star}$ & 0.618 & $-0.985^{\star \star}$ & -0.486 & -0.709 & 0.351 & -0.070 & -0.436 & -0.438 & 0.109 \\
\hline C16:1 & -0.316 & -0.772 & 0.401 & $-0.841^{*}$ & -0.578 & -0.491 & 0.025 & -0.540 & -0.667 & -0.235 & -0.022 \\
\hline C17:1 & -0.516 & -0.057 & 0.438 & -0.251 & 0.568 & -0.407 & 0.215 & 0.608 & 0.679 & -0.340 & -0.213 \\
\hline C18:1 & -0.096 & -0.672 & 0.588 & $-0.884^{*}$ & -0.399 & -0.666 & 0.514 & 0.215 & -0.269 & -0.449 & 0.224 \\
\hline PUFA & -0.498 & -0.439 & $0.988^{\star \star}$ & -0.539 & 0.092 & -0.546 & $0.907^{\star *}$ & 0.154 & -0.036 & -0.072 & 0.403 \\
\hline CLA 18:2 & -0.186 & -0.577 & 0.673 & -0.572 & -0.169 & -0.544 & 0.733 & 0.319 & -0.091 & -0.458 & 0.256 \\
\hline C18:2n6c & 0.076 & -0.437 & 0.665 & -0.571 & -0.316 & -0.094 & 0.530 & -0.171 & -0.530 & 0.222 & 0.664 \\
\hline $\mathrm{C} 18: 2 \mathrm{n} 6 \mathrm{t}$ & $0.845^{\star}$ & -0.182 & 0.527 & -0.298 & 0.411 & -0.666 & 0.293 & 0.221 & 0.459 & -0.351 & 0.368 \\
\hline C18:3 & -0.122 & 0.463 & 0.447 & 0.401 & 0.688 & -0.052 & 0.591 & 0.332 & 0.558 & 0.450 & 0.260 \\
\hline C20:4 & -0.468 & 0.349 & 0.104 & 0.487 & 0.565 & -0.028 & 0.286 & 0.130 & 0.512 & 0.054 & -0.207 \\
\hline EPA 20:5 & -0.044 & -0.061 & 0.332 & 0.036 & -0.050 & 0.240 & 0.497 & -0.352 & -0.339 & 0.312 & 0.420 \\
\hline DHA 22:6 & -0.662 & -0.014 & 0.086 & 0.124 & 0.165 & -0.542 & 0.164 & -0.065 & 0.260 & -0.313 & -0.514 \\
\hline
\end{tabular}

SFA, saturated fatty acid; MUFA, monounsaturated fatty acid; PUFA, polyunsaturated fatty acid; CLA, conjugated linoleic acid; EPA, eicosapentaenoic acid; DHA, docosahexaenoic acid. *Significantly different $(P<0.05) ;{ }^{* *}$ extremely significantly different $(P<0.01)$.

Table 4. Correlation coefficients between gene expression level and fatty acid composition in longissimus dorsi of cattle.

\begin{tabular}{|c|c|c|c|c|c|c|c|c|c|c|c|}
\hline Fatty acid (\%) & PLTP & FABP3 & FABP4 & $L P L$ & $C D 36$ & ME1 & $S C D$ & SCP2 & $A P O A 1$ & PPAR & $D B I$ \\
\hline SFA & $0.918^{*}$ & 0.056 & 0.446 & 0.414 & 0.432 & 0.067 & -0.034 & 0.356 & $-0.881^{*}$ & -0.410 & 0.273 \\
\hline C10:0 & -0.673 & -0.501 & -0.101 & $-0.858^{*}$ & -0.166 & -0.107 & -0.132 & -0.401 & 0.740 & 0.148 & -0.784 \\
\hline C12:0 & -0.837 & -0.386 & -0.249 & -0.787 & -0.291 & -0.104 & -0.083 & -0.425 & 0.870 & 0.269 & -0.678 \\
\hline C14:0 & 0.201 & 0.564 & -0.177 & 0.754 & -0.089 & 0.083 & 0.182 & 0.255 & -0.311 & 0.096 & 0.759 \\
\hline C15:0 & -0.360 & 0.443 & -0.390 & 0.409 & -0.309 & 0.034 & 0.171 & 0.011 & 0.245 & 0.303 & 0.490 \\
\hline C16:0 & $0.920^{*}$ & 0.224 & 0.372 & 0.623 & 0.385 & 0.089 & 0.022 & 0.407 & $-0.917^{*}$ & -0.362 & 0.491 \\
\hline C17:0 & 0.483 & -0.391 & 0.424 & -0.301 & 0.349 & -0.020 & -0.160 & 0.052 & -0.374 & -0.340 & -0.397 \\
\hline C18:0 & 0.739 & -0.224 & 0.475 & -0.003 & 0.421 & 0.018 & -0.118 & 0.202 & -0.653 & -0.405 & -0.129 \\
\hline C20:0 & 0.432 & 0.561 & -0.058 & $0.835^{\star}$ & 0.023 & 0.098 & 0.167 & 0.335 & -0.526 & -0.011 & 0.805 \\
\hline $\mathrm{C} 22: 0$ & -0.265 & -0.567 & 0.147 & -0.780 & 0.060 & -0.088 & -0.179 & -0.278 & 0.371 & -0.069 & -0.776 \\
\hline $\mathrm{C} 24: 0$ & 0.689 & -0.266 & 0.468 & -0.074 & 0.408 & 0.009 & -0.129 & 0.169 & -0.596 & -0.394 & -0.194 \\
\hline MUFA & 0.798 & 0.425 & 0.208 & 0.817 & 0.258 & 0.106 & 0.098 & 0.422 & -0.841 & -0.236 & 0.717 \\
\hline C16:1 & -0.775 & 0.190 & -0.478 & -0.053 & -0.428 & -0.025 & 0.109 & -0.226 & 0.694 & 0.411 & 0.077 \\
\hline C17:1 & -0.036 & -0.547 & 0.249 & -0.673 & 0.161 & -0.071 & -0.185 & -0.190 & 0.152 & -0.164 & -0.702 \\
\hline C18:1 & 0.857 & 0.362 & 0.272 & 0.765 & 0.309 & 0.102 & 0.073 & 0.425 & $-0.884^{*}$ & -0.287 & 0.651 \\
\hline PUFA & 0.226 & -0.488 & 0.347 & -0.511 & 0.262 & -0.048 & -0.179 & -0.076 & -0.108 & -0.259 & -0.574 \\
\hline C18:2 CLA & -0.155 & -0.561 & 0.198 & -0.733 & 0.110 & -0.080 & -0.183 & -0.238 & 0.267 & -0.116 & -0.745 \\
\hline C18:2n6c & 0.178 & -0.502 & 0.330 & -0.544 & 0.244 & -0.052 & -0.181 & -0.098 & -0.059 & -0.242 & -0.601 \\
\hline C18:2n6t & -0.251 & 0.481 & -0.355 & 0.493 & -0.271 & 0.045 & 0.178 & 0.064 & 0.133 & 0.267 & 0.560 \\
\hline C18:3 & 0.352 & -0.446 & 0.387 & -0.416 & 0.306 & -0.035 & -0.172 & -0.015 & -0.237 & -0.300 & -0.495 \\
\hline$C 20: 4$ & 0.689 & -0.266 & 0.468 & -0.074 & 0.408 & 0.009 & -0.129 & 0.169 & -0.596 & -0.394 & -0.194 \\
\hline
\end{tabular}

SFA, saturated fatty acid; MUFA, monounsaturated fatty acid; PUFA, polyunsaturated fatty acid; CLA, conjugated linoleic acid; EPA, eicosapentaenoic acid; DHA, docosahexaenoic acid. *Significantly different $(P<0.05)$; ${ }^{* *}$ extremely significantly different $(P<0.01)$. 


\section{DISCUSSION}

FA composition and content in yaks and cattle differed significantly, with higher levels of MUFA and PUFA and lower levels of SFA in yaks. These results agree with those of previous studies, which reported that yaks had more unsaturated fatty acids in their longissimus dorsi muscle than did cattle (Li et al., 2008; Wan et al., 2012). MUFA has a positive effect on the absorption of other fatty acids, so that it can increase the mobility and metabolism of fat globules (Schmid et al., 1998). Yak meat contained a certain amount of EPA and DHA, which were not detected in beef. The main physiological functions of EPA are lowering blood fat and cholesterol, anticarcinogenic activity, and improving brain function; DHA promoting intelligence and healthy growth and development (Dai et al., 1998). CLA is present in ruminant meat and milk, and enhances immunity, is anticarcinogenic, lowers cholesterol, and improves meat quality (Wei and Wang, 2002); the CLA content in yaks was higher than in cattle. PUFA plays a variety of physiological roles, and is extremely important in biological systems (Yu, 1998); yak meat is more nutritious and healthier than beef because of its high PUFA levels.

The mRNA expression levels of the PLTP gene were positively correlated with C18:2n6t levels in yaks, and with SFA levels and C16:0 levels in cattle. PLTP mediates the exchange of phospholipids between lipoproteins, and plays an important role in regulating the metabolism of highdensity lipoproteins and very-low-density lipoproteins (Albers and Cheung, 2004). A recent study reported that PLTP affects the n-6/n-3 ratio (Dunner et al., 2013). APOA1 (another lipid transport gene) mRNA expression was positively correlated with $\mathrm{C} 12: 0$ and $\mathrm{C} 15: 0$ in yaks, but was negatively correlated with SFA, C16:0, and C18:1 in cattle. APOA1 is an important component of high-density lipoprotein, which is a key factor in reverse cholesterol transport, and dissociative APOA1 is a cholesterol and phospholipid receptor (Wang et al., 2008). Our findings suggest that PLTP and APOA1 may play pivotal roles in lipid transport in the longissimus dorsi muscle of yaks and cattle. We also found that $A P O A 1$ expression levels in yaks were significantly lower than those in cattle, suggesting that $A P O A 1$ may be a genetic marker that is predictive of FA deposition; further research is required to identify $A P O A 1$ gene markers, such as SNPs, that are associated with FA content.

The ME1 protein is a part of the tricarboxylic acid shuttle; the nicotinamide adenine dinucleotide phosphate and Coenzyme $A(C \circ A)$ produced by the process of releasing CoA by ME1 from mitochondria into the cytoplasm are used in the biosynthesis of FAs, and in many other metabolic processes (Vidal et al., 2006). ME1 gene expression level is significantly positively related to FA synthesis in rat adipose tissue (Stelmanska et al., 2004). In the present study, ME1 expression was positively associated with $C 24: 0$ in yaks. SCD is a rate-limiting enzyme that is responsible for the conversion of SFA into MUFA by inserting a double bond between carbons 9 and 10 of the fatty acyl chain to affect the FA composition of membrane phospholipids, triglycerides, and cholesterol esters (Ntambi and Miyazaki, 2004). Previous studies have found significant differences between different genotypes of the SCD gene and FA content and composition in cattle milk and meat (Orrù et al., 2011; Li et al., 2012). In the present study, SCD expression was found to be significantly negatively associated with C20:0 and C22:0 in the yak; however, it was even more significantly positively associated with PUFA in the yak. Neither ME1 nor SCD were correlated with FA composition in cattle, so ME1 and SCD may have much more influence on FA content and composition in yaks than in cattle.

FABPs are widely distributed in a variety of animal tissues, and have high affinity with long-chain FAs and play an important role in the oxidation, esterification, and metabolism of FAs (Ockner et al., 1972; Zimmerman and Veerkamp, 1998). Fifteen types of FABP have been found, 
including FABP3 and FABP4, which are heart-type FA binding proteins (H-FABPs) and fat-type FA binding proteins (A-FABPs), respectively (Chmurzyńska, 2006). There is a significant association between FABP4 polymorphisms and milk FA composition in bovine milk (Nafikov et al., 2013). In yaks, we found that $F A B P 3$ mRNA expression levels were significantly negatively correlated with MUFA levels, while FABP4 mRNA expression levels were significantly negatively correlated with $\mathrm{C} 22: 0$ and significantly positively associated with PUFA. We did not find a correlation between FABP3 or FABP4 and FA composition in cattle. Overall, FABP3 and FABP4, particularly FABP4, may have a very important effect on FA composition in yaks, because the mRNA expression level of FABP4 in yaks was lower than in cattle.

LPL is a triglyceride-acyl hydrolase protein of the hydrolase family (Emmerich et al., 1992) that is a rate-limiting enzyme that decomposes chylomicrons in circulating lipoproteins and triglycerides of very-low-density lipoproteins, and releases FAs and glycerol. LPL was significantly negatively correlated with MUFA, C16:1, and C18:1 in yaks, while it was significantly negatively correlated with C10:0 and significantly positively correlated with C20:0 in cattle. In accordance with our data, Zhu et al. (2013) found that LPL activity is correlated with FA composition in meat. Correlation analyses revealed positive correlations between CD36 gene expression levels and C12:0, C15:0, and C17:0 in yaks, while the $D B I$ gene was negatively correlated with C20:0. However, there were no significant correlations between $C D 36$ or $D B /$ expression levels and FA content in cattle. These results provide a theoretical basis for the further study of the molecular mechanisms that underlie FA metabolism in meat (Guidotti et al., 1983; Rosendal et al., 1993; Silverstein and Febbraio, 2009).

SCP2, known as the nonspecific lipid transfer protein, enhances transport between plasma membranes and plays an important role in lipid metabolism (Starodub et al., 2000; Stolowich et al., 2002). McLean et al. (1995) suggested that SCP2 expression levels are altered in a number of diseases in which lipid metabolism is abnormal. In this study, a significant association was observed between SCP2 gene expression level and C10:0, C12:0, and C14:0 in yaks; there was no significant association between SCP2 expression level and FA content in cattle. After comparing SCP2 mRNA expression levels in yaks and cattle, we found that the SCP2 expression level in yaks was significantly lower than in cattle. These results suggest that SCP2 is important for lipid metabolism in the yak.

In conclusion, we found differences in FA composition of the longissimus dorsi muscle of yaks and cattle. PUFA is beneficial to human health, and we found higher levels of PUFA in yak meat than in beef. Of the 11 PPARa genes that we examined, the mRNA expression levels of the lipid transport gene APOA1 may have the most important influence on the FA composition of yak and cattle meat. The mRNA expression levels of FABP4, LPL, and SCP2 were also important predictors of FA composition. Our results indicate that these genes may participate in the regulation and control of intramuscular FA metabolism in yaks, and they can be used as candidate genes for FA selection in yaks.

\section{Conflicts of interest}

The authors declare no conflict of interest.

\section{ACKNOWLEDGMENTS}

Research supported by the National Beef Cattle Industry Technology System (\#nycytx-38) 
and the "Five-Twelfth" National Science and Technology Support Program (\#2012BAD13B05).

\section{REFERENCES}

Albers JJ and Cheung MC (2004). Emerging roles for phospholipids transfer protein in lipid and lipoprotein metabolism. Curr. Opin. Lipidol. 15: 255-260.

Bednárová A, Mocák J, Gössler W, Velik M, et al. (2013). Effect of animal age and gender on fatty acid and elemental composition in Austrian beef applicable for authentication purposes. Chem. Pap.-Chem. Zvesti 67: 274-283.

Cao HM, Gerhold K, Mayers JR, Wiest MM, et al. (2008). Identification of a lipokine, a lipid hormone linking adipose tissue to systemic metabolism. Cell 134: 933-944.

Chmurzyńska A (2006). The multigene family of fatty acid-binding proteins (FABPs): function, structure and polymorphism. J. Appl. Genet. 47: 39-48.

Dai CC, Yuan S and Liu JH (1998). Physiological function and application of DHA and EPA. J. Microbiol. 18: 48-50.

Dunner S, Sevane N, Garcia D, Levéziel H, et al. (2013). Genes involved in muscle lipid composition in 15 European Bos taurus breeds. Anim. Genet. 44: 493-501.

Emmerich J, Beg OU, Peterson J, Previato L, et al. (1992). Human lipoprotein lipase. Analysis of the catalytic triad by sitedirected mutagenesis of Ser-132, Asp-156, and His-241. Biol. Chem. 267: 4161-4165.

Goodson KJ, Morgan WW, Reagan JO, Gwartney BL, et al. (2002). Beef customer satisfaction: Factors affecting consumer evaluations of clod steaks. Anim. Sci. 80: 401-408.

Guidotti A, Forchetti CM, Corda MG, Konkel D, et al. (1983). Isolation, characterization and purification to homogeneity of an endogenous polypeptide with agonistic action on benzodiazepine receptors. Proc. Natl. Acad. Sci. USA 80: 3531-3535.

Hausman GJ, Dodson MV, Ajuwon K, Azain M, et al. (2009). Board-invited review: the biology and regulation of preadipocytes and adipocytes in meat animals. J. Anim. Sci. 87: 1218-1246.

Li P, Sun JX, Wang FW, Wang CT, et al. (2008). Fatty acid composition assay and function evaluation of white yak meat. Food Sci. 29: 106-108.

Li YL, Yang ZP, Wang XL, Chang LL, et al. (2012). Genotype and gene expression of SCD1 gene associated with the content and composition of fatty acid in milk. Sci. Agr. Sin. 45: 2273-2279.

McLean MP, Billheimer JT, Warden KJ and Irby RB (1995). Differential expression of hepatic sterol carrier proteins in the streptozotocin-treated diabetic rat. Endocrinology 136: 3360-3368.

Nafikov RA, Schoonmaker JP, Korn KT, Noack K, et al. (2013). Association of polymorphisms in solute carrier family 27, isoform A6 (SLC27A6) and fatty acid-binding protein-3 and fatty acid-binding protein-4 (FABP3 and FABP4) with fatty acid composition of bovine milk. J. Dairy Sci. 96: 6007-6021.

Niu XY, Guo SZ, Zhao J, Bao FG, et al. (2009). Gannan yak meat nutrition content analysis. J. Anim. Sci. Vet. Med. 2: 101-102.

Ntambi JM and Miyazaki M (2004). Regulation of stearoyl-CoA desaturases and role in metabolism. Prog. Lipid Res. 43: 91-104.

Ockner RK, Manning JA, Poppenhausen RB and Ho WK (1972). A binding protein for fatty acids in cytosol of intestinal mucosa, liver, myocardium and other tissue. Science 177: 56-58.

Orrù L, Cifuni GF, Piasentier E, Corazzin M, et al. (2011). Association analyses of single nucleotide polymorphisms in the LEP and SCD1 genes on the fatty acid profile of muscle fat in Simmental bulls. Meat Sci. 87: 344-348.

Rosendal J, Ertbjerg P and Knudsen J (1993). Characterization of ligand binding to acyl-CoA binding protein. Biochem. J. 290: 321-326.

Schmid U, Bornscheuer UT, Soumanou MM, McNeill GP, et al. (1998). Optimization of the reaction conditions in the lipasecatalyzed synthesis of structured triglycerides. JAOCS 75: 703-706.

Schmittgen TD and Livak KJ (2008). Analyzing real-time PCR data by the comparative CT method. Nat. Protoc. 3: 1101-1108.

Silverstein RL and Febbraio M (2009). CD36, a scavenger receptor involved in immunity, metabolism, angiogenesis, and behavior. Sci. Signal. Doi: 10.1126/scisignal.272re3.

Starodub O, Atshaves BP, Roths B, Murphy EJ, et al. (2000). Sterol carrier protein-2 localization in endoplasmic reticulum and role in phospholipid formation. Cell Physiol. 279: 1259-1269.

Stelmanska E, Korczynska J and Swierczynski J (2004). Tissue-specific effect of refeeding after short- and long-term caloric restriction on malic enzyme gene expression in rat tissues. Acta Biochim. Pol. 51: 805-813.

Stolowich NJ, Petrescu AD, Huang H, Martin GG, et al. (2002). Sterol carrier protein-2: structure reveals function. Cell. Mol. Life Sci. 59: 193-212.

Takahashi N, Goto T, Kusudo T, Moriyama T, et al. (2005). The structures and functions of peroxisome proliferator-activated receptors (PPARs). Jap. J. Clin. Med. 63: 557-564.

Vidal O, Varona L, Oliver MA, Noguera JL, et al. (2006). Malic enzyme 1 genotype is associated with backfat thickness and meat quality traits in pigs. Anim. Genet. 37: 28-32. 
Wan HL, Luo LT and Wu JP (2012). Research advances in yak meat quality characteristics. J. Anim. Sci. Vet. Med. 31: 36-40. Wang YL, Lu SL and Chen BS (2008). Structure and function of apolipoprotein A-I. Chem. Life 28: 279-282.

Wang Z, Yuan XP, Wang AK, Zan LS, et al. (2011). Effect of different breeds and gender of cattle on fat and fatty acid content of beef. J. Northwest A\&F Univ. Nat. Sci. Ed. 39: 24-28.

Wei HY and Wang JQ (2002). Structure and biological properties of conjugated linoleic acid. Chin. Anim. Husband. Vet. Med. 29: 14-16.

Yan WJ, Li XM and Jiang YX (2005). Analysis of fatty acid in Jinhua ham intramuscular fat and subcutaneous fat. Food Fermen. Ind. 31: 124-126.

Yang M, Long H, Wen YL, Wang JW, et al. (2008). Analysis of muscle fatty acid composition of different breed yaks and yellow cattle in Sichuan by GC-MS. Food Sci. 29: 444-449.

Yang Y, Feng YL, Li ZR, Xie XD, et al. (2006). Effect of sex and diet nutrition on the contents of flavor precursors in Fujian Haitian chicken. Acta Vet. Zoo. Sin. 37: 242-249.

Yu WS (1998). The research situation of polyunsaturated fatty acids. Foreign Med. Sci. (Hygiene) 25: 359-362.

Zhu RZ, Yin XH, Wang YH, Li SQ, et al. (2013). The gene expression of MDH and LPL in muscle and their association with content of intramuscular fat and composition of fatty acids in pigs. Acta Vet. Zoo. Sin. 44: 1182-1188.

Zimmerman AW and Veerkamp JH (1998). Members of the fatty acid-binding protein family inhibit cell-free protein synthesis. FEBS Lett. 437: 183-186 